\title{
RESET
}

Recherches en sciences sociales sur Internet

\section{Information-Seeking 2.0}

The Effects of Informational Advantage

La recherche d'information 2.0. Les effets de l'avantage informationnel

\section{Laura Robinson}

\section{(2) OpenEdition}

Journals

Electronic version

URL: http://journals.openedition.org/reset/135

DOI: $10.4000 /$ reset.135

ISSN: 2264-6221

Publisher

Association Recherches en sciences sociales sur Internet

\section{Electronic reference}

Laura Robinson, «Information-Seeking 2.0 », RESET [Online], 1 | 2012, Online since 30 December 2012, connection on 02 May 2019. URL : http://journals.openedition.org/reset/135; DOI : 10.4000/reset.135

This text was automatically generated on 2 May 2019.

(c) Association Recherches en sciences sociales sur Internet 


\title{
Information-Seeking 2.0
}

The Effects of Informational Advantage

La recherche d'information 2.0. Les effets de l'avantage informationnel

\author{
Laura Robinson
}

\section{Digital Inequality: The Endemic Importance of Class}

1 The present work targets the effects of social class on the perpetuation of digital inequality. Previous studies of digital inequality have shown the detrimental impact of lack of Internet access on different groups of people (DiMaggio et al., 2004; Mesch \& Talmud, 2010; Witte and Mannon, 2010; van Dijk, 200511). Important foundational works examined how different disadvantaged groups had varying access to computers and/or the Internet. Early scholars of what was then referred to as the "digital divide" warned of the chasm between those with and those without Internet access. With good reason, early studies of the digital divide showed how Internet access was concentrated in the hands of those holding the reins of power in terms of gender (Kotamraju, 2003), class (van Dijk, 2005), education (Cotten \& Jelenewicz, 2006), and race/ethnicity (DiMaggio et al., 2004). In sum, in the first years of the Internet, women, non-whites, rural dwellers, older generations, and those with less education and/or less income were the most likely parties to be digitally excluded (van Dijk, 2005).

2 Even today digital inequality continues to be a global phenomenon impacting even highly developed countries where segments of the population remain digitally excluded. In his 2005 study, van Dijk surmised that $20-35 \%$ percent of individuals in developed societies were still excluded from new media resources (178-79). Even as late as 2008, significant percentages of the American population were yet to enjoy even "occasional" access to Internet technologies (Pew, 2008). In 2008, only 53\% of individuals from households with less than $\$ 30 \mathrm{~K}$ annual income, $63 \%$ of rural populations, $44 \%$ of individuals with the lowest levels of educational attainment, and $35 \%$ of those 65 and over used the Internet "at least occasionally." 
Only two years later, class differences remained the strongest predictor of digital inequality. In May 2010, another Pew report showed that certain gaps had closed or were closing among American adults. According to Pew, the gender gap in access had disappeared with $79 \%$ of both men and women reporting Internet use. While $79 \%$ of all Americans reported using the Internet, some race and ethnicity Internet use gaps still existed. Latino Americans jumped ahead of European Americans at $82 \%$ compared to $80 \%$; the percentage of African Americans using the Internet increased to $72 \%$. In tandem, Witte and Mannon also found that gender and race/ethnicity had become less reliable predictors of Internet access (2010). Indicating the association between poverty and rural residency, there was a 14 point gap between the two. Rural populations $(67 \%)$ had only increased marginally, still lagging behind their urban counterparts (81\%) in basic Internet access. Therefore, by far the most persistent gaps in Internet access in the United States continued to be related to class differences: educational background, income, and rural dwelling (Pew, 2010).

\section{From Access Gaps to Skills Gaps}

Differences in access lead to other kinds of gaps. Skills gaps are another facet of digital inequality that further strengthen the negative effects of disadvantage. Schradie's (2011) analysis affirms the importance of class by drawing important connections between digital inequalities and capital-enhancing activities such as skill building. According to her study, quality online access at home, school, or work is a significant factor determining the degree to which individuals possess certain digital skills. Schradie's argument that class variation accounts for the degree to which individuals can engage in and subsequently benefit from new media are at the forefront of work on digital inequality and indicate the deep need for research uncovering the feedback loop between access to resources and benefits accruing from them.

Other studies have also indicated the importance of acquiring particular "digital skills" (van Dijk 2005: 73). Skills related to finding and assessing information constitute one of the building blocks of information literacy. Mastery of digital skills is a precondition for the acquisition of informational advantage. Not only do more-skilled Internet users reap benefits by obtaining desired information with less effort, but they also use the Internet in a more flexible and versatile manner than less-skilled users. Studies have found that more-skilled users transition more easily from one website to another and enlist the Internet for a more varied menu of human capital-enhancing activities (Witte \& Mannon, 2010: 95-113). Skills allow users to use the Internet effectively, which in turn gives "wired" individuals advantage compared to their less-wired counterparts in personal and professional life spheres (DiMaggio \& Bonikowski, 2008).

6 Just as the literature has succeeded in illuminating the importance of digital skills gaps, it has identified many of the determinants of digital skills. First, higher levels of digital skills go hand in hand with a higher intensity of usage, longer user histories, and broader arrays of online activities (Peter \& Valkenburg, 2006; Hassani, 2006). Individuals who use the Internet more intensively are most likely to expose themselves to a variety of online sources of information. In consequence, those with greater intensity of use and exposure to varieties of information also tend to develop better digital skills. As these three immediate antecedents (intensity of use, variety of information exposure, and skills) tend to vary directly with better conditions of access and higher socioeconomic status, it is 
clear that patterns of digital skills stratification indirectly reflect the conditions of access to online information sources (Robinson, 2009; van Dijk, 2005). All else being equal, users who enjoy more autonomous and less constrained access to Internet resources tend to outpace counterparts with less autonomy and more constraints. Since conditions of access generally track socioeconomic and other offline disparities, it is not surprising that individuals higher up in the socioeconomic stratification order tend to exhibit better digital skills (Witte \& Mannon, 2010).

7 These inquiries into the genesis and consequences of digital skills broadly defined have convincingly demonstrated how digital skills enhance life chances and, at the same time, how skills themselves are the indirect product of particular life circumstances. However, previous work does not go far enough in terms of uncovering the consequences and origins of digital skills. If the term "digital skills" is taken in the broadest sense, then it encompasses not only specific capacities relating to such activities as computer operation and web searches but also what van Dijk calls "strategic skills" (van Dijk, 2005: 88). A user equipped with good strategic skills has the capacity to harvest useful information from online sources and deploy this information to great effect.

While valuable, most studies do not attend to the precise character of the informationacquisition and assessment processes favored by various kinds of Internet users. Previous work does not reveal how these processes relate to either individuals' internalized propensities or to social, temporal, and material resource environments. They neglect to ask, in other words, how particular orientations and resource environments shape use of the Internet for information-acquisition (Kuhlthau, 2004). Indeed, work is needed to make clear whether exposure to different kinds of traditional and digital informational resources allows individuals to acquire and assess information in distinctive ways that reflect these internal and external contingencies.

\section{Theoretical Orientation and Analytic Strategy}

9 Clearly, this issue merits a sustained and focused examination. In this article, I do so by examining information-acquisition and assessment vis-à-vis the as of yet underdeveloped concept of informational advantage. Informational advantage may be seen as the dimension of information capital, connected with the skills and resources, necessary to what Hamelink terms the "capacity to filter and evaluate information" and the "capacity to translate information" into practice (2001). In this way, the term informational advantage captures the passive aspect of information capital arising from the exposure to informational resources and the active aspect of information capital connected with the ability to deploy information effectively in pursuit of goals. Van Dijk summarized Hamelink's definition of information capital as indicating "four abilities: (a) the financial ability to pay for the costs of computers and networks, (b) the technical skills to deal with them, (c) the capacity to filter and evaluate information, and (d) the motivation to look for information and the capacity to use this information in society" (2005: 72-73).

In this article, I capitalize on the notion of informational advantage in order to explore the connections between individuals' exposure to particular kinds of informational resources - both online and offline - and their information-acquisition and assessment practices. In making these connections, I show that non-digital media and informational resources must be included in any examination of informational advantage: exposure to digital resources cannot be analyzed in isolation. Rather than limiting informational 
advantage to refer only to individuals' dealings with new media, it must incorporate information from non-digital sources such as books, TV, magazines, radio, newspapers, and people. Expanding the notion of information capital as informational advantage will allow us to understand 1) how digital inequality is embedded in larger informational inequalities and 2) how digital inequality can further exacerbate other informational inequalities stemming from unequal access to non-digital informational resources.

11 To advance this goal, the present inquiry explores how more and less informationally advantaged youths from varied socio-economic backgrounds bring different kinds of informational resources to their encounters with new media. It illuminates how these differently situated youths experience their informational environments and what kinds of information-assessment strategies they develop as a result of these environments. These differing assessment strategies are explored in light of their implications for both schoolwork and students' efforts to learn about their college options. As the analysis will show, informationally disadvantaged students' compensatory strategies are damaging for long-term information-assessment and when used to gather information relevant to college planning.

In order to better examine the links between informational advantage and informational environments, this study focuses exclusively on students' information-seeking acquisition and assessment practices relating to academic achievement. Significantly, the research zeroes in on academic high-achievers to the exclusion of other kinds of students so as to effectively hold motivation constant across comparison groups. By holding motivation constant, this exploration reveals how equally driven students with unequal access to informational resources mobilize different strategies to acquire information and internalize different beliefs about their authority to assess the information they find.

The high-achieving students selected for analysis meet the following criteria: 1) they have chosen to take accelerated college preparation courses, 2) they firmly intend to earn a B.A. or B.S. college degree, and 3) they take initiative to find needed resources to meet these goals. They are academic achievers who are engaged in their schoolwork and committed to maintaining academic excellence required to prepare for college. These students are committed to meeting the criteria to ultimately attend a four-year college or university to earn a Bachelor of Arts or Bachelor of Science degree ${ }^{2}$. However, these students are the exception rather than the norm in their immediate school environment. The students in this analysis attend a public high school in an agricultural region of California where the majority of their peers do not apply for admission to a four-year university immediately after high school. In this school, regardless of students' intellectual abilities, attending a four-year college is not taken for granted as it would be in a more affluent milieu. The school site was specifically chosen to isolate a subset of students whose normative environment is unlike that of high school students in economically privileged high schools, who may as a matter of course expect to attend four-year institutions. By selecting these high-achieving students from a larger population of disadvantaged students, their special attributes are thrown into high relief. By examining only the subset of students meeting these selection criteria, motivation is held constant to reveal the significance of informational advantage. 


\section{Data and Methods}

14 The data analyzed here are drawn from a multi-year study of digital differentiation among economically disadvantaged high school students living in an agricultural community in California. The larger study was conducted from 2006 to the present by combining ethnographic fieldwork, focus groups or small group interviews, one-on-one interviews, and surveys. Qualitative data was drawn from small-group and one-on-one interviews with over 500 students from multiple schools and grade levels.

This article examines a subset of the data from the small-group and one-on-one interviews. The data anchoring this paper come from interviews with high-achieving high school students from a single low-income school. The interviewees are economically and ethnically diverse. A significant proportion of the students qualify for free lunch, indicating that the most economically disadvantaged come from families with incomes falling below federal poverty measures. Another measure of disadvantage is the school's classification by the state of California as a "Title I" school or a school whose population has been designated by the State as being among "California's highest-poverty schools ${ }^{3}$."

Data collection was administered through the English Department because all respondents must take four years of English courses. This strategy forestalled biased data collection or "cherry picking" of interviewees that would skew the results. Interviews were conducted on the school campus during normal school hours. Questions covered topics including but not limited to:

1. access to and use of informational resources (digital, traditional media, and people) in terms of quality, frequency, and duration in the home, school, public venues, and third places

2. skill-learning opportunities in terms of quality, frequency, and duration in the home, school, public venues, and third places

3. information-acquisition and information-assessment practices

4. time allocations and daily routines

5. temporal and transportation resources

6. educational careers in high school

7. educational and professional aspirations after high school

Every interviewee was given the opportunity to answer every question although participation was optional. The data from both one-on-one and small-group interviews were systematically compared to ensure consistency. While the very rich data provide an excellent foundation for "discovery-oriented" analysis (Luker, 2009), this method does not allow for the testing of hypotheses regarding cause-effect relationships among prespecified factors.

Rather, the analytic categories emerged from the data through an iterative process of constant comparison rather than being imported from previous works. Analysis relied on a grounded approach ideal for emergent phenomena such as new media (McMillan \& Morrison, 2006). Emergent themes were employed as sensitizing elements rather than theories to be tested according to the logico-deductive model. My goal was "to arrive at theoretical propositions after having looked at the social world, not before" (Emerson, 1983: 93). According to Luker, this kind of approach is an excellent method for the elaboration of emergent conceptualizations and explanatory accounts, rather than the verification of hypotheses or testing of a priori conceptualizations (2009). Using this 
strategy, I generated analytic frames by relying more on induction from empirical data than on deduction from theoretical postulates (Alford, 1998).

More specifically, the initial coding of the data revealed potential linkages between exposure to informational resources of various kinds and patterns of informationacquisition. Employing open coding, I further identified connections between respondents' informational environments, information-acquisition efforts, and information-assessment practices. Open coding also allowed me to identify different normative informational resources in the home, as well as temporal opportunities and constraints in accessing these resources outside of the home. With these emergent analytic categories, I noted connections between informational environments and respondents' strategies of information-assessment. I also identified the ways in which these assessment practices articulated with schoolwork and college planning activities. I confirmed these patterns as I continued inductively coding the data.

Subsequently, I developed targeted codes regarding informationally advantaged and disadvantaged students, home and familial information resources, autonomous and dependent information-acquisition and assessment, and patterns related to schoolwork and college planning. I used focused coding to confirm patterns. This process ensured that the analytic categories were grounded in the data. I used this iterative process to develop generalizations. Subsequently, I used multiple rounds of code and recode to verify the generalizability of findings to the entire data set. Finally, it should be noted that the present analysis draws upon data collected in a single geographic region of the United States. The goal is to illuminate an understudied phenomenon rather than generalize the findings to any larger population.

\section{Analysis: Meet the Achievers}

21 To illustrate the range of advantaged and disadvantaged students, representative exemplars are presented for two groups: informationally advantaged and informationally disadvantaged students. Each group is comprised of four students: two female and two male graduating seniors. As representative cases, they have been matched and systematically compared with the larger groups of advantaged and disadvantaged students along relevant axes. This matching strategy (Schulz, 2012) ensures that they exemplify the general patterns characteristic of the subcategories of informationally advantaged students or disadvantaged students to which they belong.

Celia ${ }^{4}$ and Micky, as well as Betty and Ronaldo, are representative of the range of economically and informationally advantaged students who experience plentiful information resources as normative. The most richly advantaged students are exemplified by Celia and Micky. Both come from homes where white-collar, professional careers are the expected norm for them and for their siblings. Betty and Ronaldo represent informationally advantaged students whose parents hold skilled work, often requiring study past high school such as certification at a community college. Drawing on information-rich environments, advantaged students adopt a playful stance towards information-assessment. These students have a high tolerance for risk in their encounters with new media because they have the luxury of time and resources with which to treat information-acquisition as a form of play (Robinson, 2009). 
Whereas advantaged students experience information abundance in both their offline and online environments, disadvantaged students experience information scarcities including lack of quality home Internet access, lower levels and quality of traditional media in the home, and family members less able to act as informational resources. Stephanie and Vladimir, as well as Rosalia and Russ, are representative of the range of economically and informationally disadvantaged students who experience information scarcities as normative. Disadvantaged students like Stephanie and Vladimir come from families lacking both economic stability and steady income; some have parents without regular employment. Rosalia and Russ come from the most precarious and most disadvantaged background of any of the students: the working poor with one or more parents employed in unskilled work. Because both of Rosalia's parents work in the fields, on top of maintaining her studies, Rosalia is responsible for manning the home front to take care of her younger brothers and sisters. Russ is head of his family since his father left. As "man of the house," he works part-time and takes care of his mother and younger siblings, leaving only the evening hours for many hours of homework required for college prep courses.

\section{Normative Informational Environments}

\section{Informationally Advantaged Students}

Celia and Micky come from wired families in which parents and siblings have multiple computers or individual laptops, as well as a sophisticated mastery of new media technologies. Both were early Internet adopters and were taught how to use the computer and Internet by their parents and, in Micky's case, older siblings. Now when it comes to the Internet, Celia and Micky claim they have begun to teach their parents more than learning from them: "Showed my dad Google Maps. Now he uses it all the time" and “...set up my mom's Flickr account for the pics from vacation - very cool." Betty's family shares a high-performance computer with high-speed Internet access: "We take turns 'cause my parents do stuff for work on the computer, but when I have something for school my parents are really good about that and let me go first... as long as necessary..." Ronaldo has recently acquired his own laptop with wireless Internet, which he says has "freed me up from competing with my sister... cannot get the girl off the machine." Like Celia and Micky, Betty and Ronaldo's parents are competent Internet users who originally taught them how to use both computers and the Internet. Further, like Celia and Micky, Betty and Ronaldo report that they can now teach their parents the latest new thing: "Yeah I had to set up my mom's account for her - she could've done it, but I'm faster."

Regarding traditional media, Betty's family enjoys the local newspaper and several general-interest magazines such as Better Homes and Gardens. Ronaldo's family also subscribes to specialty and industry publications in addition to the local "fish wrap" as Ronaldo's father calls the local paper. Both Betty and Ronaldo's families have extensive cable TV with sports, movie, and specialty channels. While Ronaldo enjoys his motocross magazines, Betty is more likely to "dip into a good book" than fashion magazines if she has time on her hands. Both have sets of encyclopedias although Ronaldo said that he hasn't, “...really used it since junior high when we got the computer." While they do not share the range of cosmopolitan media normative to Micky and Celia, Betty and Ronaldo's families stay informed, "look at the local news at night," "keep an eye on events," and 
stay abreast of local politics. In addition to digital media, Micky's home contains hundreds of books, an encyclopedia set, a range of print reading materials such as National Geographic, and a subscription to a national newspaper. Celia's home also has a range of print materials, as well as a large DVD and music collection. While they have different preferences in their leisure activities, both Celia and Micky use offline and online informational resources on a regular basis for schoolwork and for pleasure. A bookworm, Micky reads daily, is always on the lookout for new books and magazines, and still enjoys the family's print encyclopedia set, which Micky refers to as "conveniently located in the bathroom for easy access." Celia is also an avid reader, although she makes time for her favorite guilty pleasures, "mindless TV shows," thanks to a premium cable package.

\section{Informationally Disadvantaged Students}

Stephanie and Vladimir both feel the effects of the economic downturn on their home media environment. Stephanie doesn't have home Internet "right now," but still has use of a computer and printer although, "I have to watch out how much I print "cause ink is really expensive." For Stephanie, initial Internet exposure occurred at a friends' house. Stephanie's parents bought the family computer in better times "to help me with my schoolwork." Vladimir's first experiences using the Internet were in school supervised by a teacher. His parents, like Stephanie's, saw buying a computer as an investment in their children's education. Vladimir explains that his computer is "on the fritz... and really slow" but that he can "still get it to work." Vladimir's quality of home access has varied due to economic constraints: "We started out with dial-up and then we switched to DSL and then we switched back to dial-up." Neither Rosalia nor Russ has home Internet access. Both learned their computer skills from teachers and classmates in school settings rather than from their parents. Russ shares that he and his siblings used to have an old computer where he could type up his essays, but "then it broke but we didn't have the money to fix it." Both Rosalia and Russ are largely dependent on Internet and computer access provided by their school. Occasionally, Rosalia goes to her aunt's house, but given her responsibilities at home, it is difficult as she explains, "I can't leave my little sisters at home alone to go to my aunt's very often, so I don't use the computer as much as I would like to." When he is not at his job, Russ goes to the public library when he needs a computer or the Internet: "I found these old computers up with the books. No one wants to use them because they don't have Internet, so sometimes I can type up my homework essays that way if I don't have to go to work."

In disadvantaged students' homes, traditional media are significantly more limited than in the homes of their more advantaged peers. They are unlikely to have the glossy magazines, home encyclopedia sets, or platinum cable packages made possible by disposable income normative to Micky and Celia. This being said, their parents do their best to provide for their children. Vladimir says, "I don't like to ask, but if I really need a book or something, my mom will buy it for me." Stephanie echoes, "My parents try hard to get us what we need, but times are hard right now and we have to be careful." Rosalia and Russ have few books and magazines. Instead, they mostly rely on the library to check out materials. However, they have less time to read for pleasure. Russ explains, "I'd like to read more, but by the time I get home from work, I have just enough time for my homework before going to bed. I'm hoping that when I have my real job, I'll have more 
time to read stuff 'cause I like to know what's going on in the world." While their families do not subscribe to magazines, they pick up freebie weeklies at nearby convenience stores. Neither has a cable package, only the local networks and other "free" television stations. Rosalia shares, "I try to keep up on things by having the news or the TV on while I'm doing chores around the house."

\section{Information-Acquisition Strategies}

\section{Informationally Advantaged Students}

With regard to information-acquisition and assessment strategies for schoolwork, informationally advantaged students are alike in several respects. First, media in the home provides a knowledge base that informs online information-acquisition. Family members, in tandem with home media, act as resources for information-acquisition, as well as information-assessment. These resources work together to boost advantaged students' ability to determine veracity and reliability when assessing online information. Plentiful informational resources facilitate successful online information-acquisition and accelerate advantaged students' facility with information-assessment. Typically, these processes work together to give advantaged students confidence in their own abilities to arbitrate between different information sources and draw their own opinions regarding online information.

Access to home media resources builds up a pool of knowledge that informs their acquisition of information online. Betty relates, "So when I had this report for school, I remembered seeing a show [on TV] with my dad. I used what I remembered to start off my searches." Micky explains, "Well even though they are kind of old, I've picked up all this random knowledge from our encyclopedia. Weirdly comes in handy sometimes for school... like I knew that gods had different Greek and Roman names so I could google "em both." Betty says, "My dad is a total news freak. Makes us all watch at dinner... but sure helped me out in my econ[omics] class... made doing the research for that one totally easier."

At the same time, home print media can act as a grounding point for online informationacquisition and assessment for school. As Micky says, "So it was down to the last minute on this assignment, so I went straight to Wikipedia. Pulled out ye olde encyclopedia to compare and get a feel if wiki was givin' me the real-deal." Celia adds her own example, "I happened to read this old book kicking around the house... and when I was finding all this junk online... like I re-read this one part of [the book], then I knew where to start lookin'." Ronaldo contributes, “...yeah like for government [class], I dug out all the stuff from our trip to D.C.... made it much easier to start with what I knew and then get the information that I still needed later... knew what to look for..."

31 In addition to traditional media, many make use of family members as convenient and reliable information sources that inform their use of the Internet for schoolwork. As Ronaldo says, "Yeah. If I have a question sometimes I can ask my dad where to start. He is really interested in history and will give me ideas on what to look for... then I may end up looking up stuff for other than school - that's another problem." Celia uses a similar strategy with her literature assignments, "My mom reads all the time... she almost always knows something about authors and books... can suggest a bunch of stuff, then it's up to me to choose." Micky adds, "Bugging brothers is always an option, not always the best 
"cause then they can go off on something else, but always an option." Advantaged students agree that having instant access to knowledgeable family is a quick and easy way to acquire school-related information that can spur web surfing.

Even more important, plentiful and comfortable informational environments provide a powerful sifting mechanism for online information-assessment. Advantaged students can use multiple resources at the same time. In addition to "checking" online information against traditional media sources, advantaged students can turn to their parents as a knowledge resource as does Betty: "We've got a computer in the kitchen, so if my mom is cooking, I can ask her questions while I am looking up junk for school... helps to have someone right there." Just as parents and siblings can help with information-acquisition, they can provide advice. Micky explains, "Oh yeah called in my brother for back up... he's already at college and told me that [the website] was... let's just say for the birds." Celia admits, "If I get home late and I'm just really tired, I'll ask my mom to look over [online content] with me and go over it..."

Equally important, home media, knowledgeable personal networks, and quality homeInternet access work in tandem to enhance optimal information-acquisition and assessment. Betty shares, “...if I am working on somethin', I can always text one of my friends who is probably working on the same thing... she works at her house... I'm in mine, but yeah we are working together... can say 'go here' and give her the website... multi-tasking together." Vladimir confirms that information sharing in information-rich environments is another strategy that works to maximize efforts: "If we have something due... he'll [a friend] come over and I'll have my laptop open and he'll have his and so we'll start googling at the same time, kinda compare notes as we go to see what's right... one time my dad overheard us going back ' $n$ forth and joined in... kinda fun in a geeky way..." Just as those with high-quality home access can use one online resource to verify another at will, they can also turn to well-informed people in their immediate informational environment for instant verification.

Significantly, thanks to resources, advantaged students experience information as consistently present and accessible. Parents, siblings, and traditional media are always "there," always available for use. This is equally true of online information. Celia explains her practices, "No I don't bookmark anything. I have my own laptop. I'm the only one who uses it. So I search for things. If I look at the information again, the link is purple so I know I've seen it." Micky shares, “...no never have to worry about [losing information]... I can always pull up the history if I need to find something again." Ronaldo confirms, "Nah I don't need to save everything [from the Internet]... it's there if I need it." Advantaged students experience constant immersion in informational resources giving them confidence that the online information they need is always at their disposal.

\section{Informationally Disadvantaged Students}

Students with fewer resources are no less eager to acquire and assess online information. However, their experiences using the Internet for schoolwork are informed by different constraints than those of their more informationally advantaged counterparts. Unlike advantaged students who benefit from continuous access to informational resources, disadvantaged students must continuously seek for information outside of the home. Therefore, the strategies adopted by disadvantaged students require additional effort above and beyond that exerted by their better-resourced peers. 

do not enjoy traditional media in the home as a plentiful resource. As Russ shares, "If I need a book for school, I have to go to the library." Stephanie confirms, "...not too much at home for school... gotta go to the library." To get what they need, they find solutions that often mean going the extra mile. Vladimir shares how he went across town to hunt down a book he found online: "I found one book in JSTOR that actually had most of the information on my topic but I couldn't access it so I actually went to Jefferson [community college] and the lady, she told me she was gonna look for it. She called me back that she didn't find it but she found another book [online] that had the same idea as the one I was looking for and she let me borrow it right there..." Vladimir doesn't receive his first choice book, but he makes do with what he has. Then he solves another problem. Because he is not allowed to take the book home and cannot print it, he has to find another solution: "I just took a piece of paper and most of the notes that I took were on that book and I just wrote them down." Rosalia finds other ways to meet her needs, "When I told Mrs. Fox... she let me take home books from her classroom."

Finding solutions is a constant theme among informationally disadvantaged students. Lacking home access to media requires one set of solutions. However, other solutions are also required for these students to fill the informational gaps created when they cannot rely on their parents as informational resources. Vladimir reports, "....better to ask a teacher... nobody to help me at home." Rosalia confirms, "Can't really ask my mom to help me with schoolwork." To fill this gap, disadvantaged students seek out educators who can act as informational resources for those lacking at home. Rosalia states, “...had a paper on Shakespeare, but I didn't know too much about it.... had to start from scratch... got Mrs. Caper to let me use [one of] her computers by coming in at lunch and asking for extra help... she let me come in a lot." Stephanie shares, "I found out that Mrs. Fenwick had a kind of homework club in the morning... let anyone who wanted to come in and work with her, use her computers... I was all over that." Educators also include librarians and other knowledgeable adults. Russ recalls, "I got to know Mrs. O'Neil in the lab. She lets me come in and work, lets me print, AND she answers my questions." These students use a similar strategy with peers with more resources. Russ states, "Yeah my cousin helped me out... he showed me what to do..." Stephanie relates, "It was ok because I was friendly with some of the girls in the class. They could show me what to do." Vladimir explains: "I like it when they put us in groups so that we can help each other."

While students of all backgrounds can go to educators for help or swap information with peers, many disadvantaged students have no or low-quality home Internet access, meaning they must often rely on public access or personal social networks for all their informational needs ${ }^{5}$. This means that they do not experience simultaneous access to traditional media, knowledgeable parents, and high-quality Internet access to inform their online information-acquisition. Disadvantaged students experience online information-acquisition in isolation rather than information-acquisition drawing on plentiful informational resources. The costs of finding solutions mean that though successful in meeting basic needs, their compensatory strategies allow them to merely keep up rather than vaulting forward. Rosalia shares, “...it's harder for me 'cause I don't have what I need at home... it's hard having to depend on other people just to get my work done." Russ affirms, "I just have to do more. It's ok. It's ok. I just have to do more." Vladimir says, "Yeah maybe other people got more stuff. Whatever. I just gotta get it done."

RESET, 1 | 2012 
However, even if they fill these gaps by "doing more," their compensatory strategies necessitate sequential searching. By necessity, online information-acquisition takes place independent of offline information-acquisition. Russ explains, "I can lug my textbooks or books from the library with me to the computer lab I guess. But there isn't any space to spread out my stuff." Unlike informationally advantaged students who can engage in informational multi-tasking while online (grabbing a book from upstairs, asking mom a question, texting a friend for help, taking a break to eat dinner and look at the news with family, etc.), disadvantaged students have to take an expedient approach that precludes taking time to simultaneously engage with other informational resources. Rosalia explains, "It's like hard enough getting time [on the Internet in the lab]. I can't just take a break and jet to the library like 'oh time out and hold my place for me."' Access to limited resources often forces disadvantaged students to appropriate information in a sequential manner that has far-reaching implications for their college planning.

\section{Information-Assessment \& College Planning}

\section{Informationally Advantaged Students}

Finally, informationally advantaged students successfully integrate online and offline informational resources. For them, repeated success breeds confidence in their abilities to acquire and assess information for schoolwork. These students grow to believe in their ability to find the information they need as a result of habitually drawing on a variety of informational sources. Betty relates, "Yeah I'm pretty sure that I can find what I need and make a pretty good guess on where to take it... if I need to, I can look up the information and confirm it..." Ronaldo says, "I'll do ok... decide what's true [online] and what's not as long as it's something that I know something about or it's at least something that I can look up...” Micky concurs, “Unless it is really specialist information - I don't know [such as] rocket science or something - I can get it. I mean I may not write a book about it, but I can get it." Celia sums up, “...might take me awhile to compare everything, but more often than not, I'm good to go."

Confident in their ability to assess the accuracy of information, advantaged students develop an autonomous stance both for schoolwork and for college planning. Regarding college planning, rather than deferring to educators' judgments, they actively seek out information. As Betty reports, "I read US News and World Report and then visited sites of schools that looked good... even found a site with student reviews..." Constantly comparing information from on- and offline sources, advantaged students assemble prioritized lists of prospective private and public colleges based on their individualized research. Celia relates: "After talking to my brother's friend, I decided to apply to Berkeley... also found some privates on collegeboard [website]... I used the filters and came up with my top ten after comparing the kinds of financial aid they give." The students select colleges based on multiple criteria including academic programs, financial costs and aid, as well as their perceptions of fit. Micky tells a similar story, "...scoped out some schools online... talked with my dad... went back online... in the end I found a good private school that offered tuition matching with the UCs... showed it to my dad - he is totally on board ${ }^{\prime \prime}$. When using the Internet to research colleges and universities, advantaged students are able to compare and contrast information from on- and offline sources to make their own well-informed decisions. Ronaldo explains, "...like some 
teachers were pushing the CSUs but I found great engineering programs out of state just by googling..." As these examples indicate, informationally advantaged students capitalize on their ability to acquire, integrate, and assess information from multiple sources. Confident in their ability to assess information on their own, they easily arbitrate between multiple sources of information relevant to one of life's most pivotal decisions: college planning.

\section{Informationally Disadvantaged Students}

By contrast, informationally disadvantaged students internalize the need to "catch up" and to validate information for schoolwork with trusted opinions. Rosalia states, "Eventually I guess that I can get what I need, but there is so much to learn." They lack the background knowledge that would maximize their efforts to acquire information online. Vladimir echoes, “...maybe if I had more time I could use more [Internet] sites, but it speeds things up to use places my teachers has told us about. Then you know you are on the right track... if a teacher tells me where to go, that's my first stop." For disadvantaged students, relying on trusted opinion to guide online information-assessment is a central risk-management strategy. Lack of resources creates a cyclical process in which disadvantaged students lack the knowledge base created by plentiful informational resources in the home. Russ shares, "...so it's smarter for me to go where a teacher tells me it's good... I don't want to get something wrong..." This strategy is relatively successful in the short-term. However, long-term reliance on trusted opinions from educators inhibits disadvantaged students from becoming autonomous in their information-assessment.

Significantly, for informationally disadvantaged students, reliance on educators' opinions carries consequences for college planning. As with their schoolwork, they report relying on educators whose opinions they trust. Rosalia turns to her teachers for guidance on her college search: "Our class went to the College Center... there was way too much information so I talked to Mrs. Dwight. She told me to apply to CSUs 'cause they're cheaper... and I trust her... no I didn't consider any other schools." By limiting options to those specified by her teacher, Rosalia radically limits her college options by excluding more expensive institutions. Stephanie also recounts taking educators' opinions as gospel truth, “My family hasn't gone to college... so I went to Mr. Hart... he told me not to waste time looking up privates [universities]... they are way too expensive and to not even look at them so I didn't... I mean what's the point?" Russ also limits his college search to schools explicitly specified by educators: “I tried to use collegeboard but I didn't even know how to answer their questions... Mr. Morales really helped me... he explained everything... told me not to take loans for a four-year school when I can go to Jefferson [community college] instead..." When these disadvantaged students defer to educators advocating what they believe are more cost-effective options, students unwittingly foreclose opportunities that could better serve their educational interests. This is particularly deleterious for top students with strong academic records who stand a chance of getting better financial aid at more prestigious universities. Ironically, informational disadvantage compromises self-investment for the very students who need it the most. 


\section{Conclusions and Implications} This research contributes to our understanding of digital inequalies by developing the concept of informational advantage. The work begins to flesh out the causes and consequences of informational advantage in all its aspects. We have seen that the information-acquisition and assessment practices embraced by informationally disadvantaged students stand apart from the practices enacted by their more informationally advantaged counterparts. Even with all of their efforts, disadvantaged students are forced to acquire educational information in a highly constrained fashion, mining each informational resource as they gain access to it. Without resources to waste, they maximize their chances of success by relying on trusted opinion to guide the information-acquisition and assessment process in its entirety. For these students, educators are responsible for both the direction of initial information-acquisition efforts and the subsequent validation of students' information-assessment. While disadvantaged students collect offline and online information themselves, they routinely consult with educators to validate their results before proceeding. Forced by necessity to husband their resources, their primary goal is to find the "right answer" that produces good grades for school work. The need for educators' repeated validation of information "to stay on track" necessitates a highly constrained process grounded in repeated consultations with the educator.

This "taste for the necessary" (Bourdieu, 1990) creates a pattern in which agency always rests outside of informationally disadvantaged students' hands. While this low-risk strategy works well to earn high grades necessary for college admissions, in the long term it actually impairs students' capacity to weave together pieces of information from various sources into a coherent whole. This strategy ultimately keeps those who practice it reliant on others and hinders them from internalizing the capacity to make these decisions themselves. Most important, from the students' perspective, this process appears entirely rational, as it allows them to achieve "success" in terms of high grades, even if it means that they continually defer to others' opinions. But, in reality, this strategy ultimately hinders them from fully realizing their capabilities as autonomous information assessors. Their inability to assess information autonomously is especially problematic during the college-search process. Those informationally disadvantaged students who rely on educators' opinions may inadvertently curtail their college options. In this way, the damaging consequences of informational disadvantage impact the college-search process, a process with lifelong implications.

Informationally advantaged students, by contrast, are in a position to integrate pieces of information from diverse sources in their schoolwork and their college searches. With many "second chances" at their disposal, informationally advantaged students often engage in multiple rounds of recursive information-acquisition and assessment. The freedom to draw on multiple information sources enables these students to initiate multiple information forays in parallel. These advantaged students carry out numerous rounds of information collection - whether they involve online or offline information sources or a combination of the two sources - and arbitrate between conflicting pieces of information. Internalizing belief in their own capacity to render judgments autonomously has significant ramifications for the college-search process. When seeking information on colleges, rather than primarily relying on educators to make judgments 
about the credibility and reliability of information obtained from online sources, informationally advantaged students direct their own information-acquisition and assessment activities. While they gather educators' opinions, ultimately these advantaged students judge between different sources of information. Informationally advantaged students draw from a richer menu of options in the college-search process, which provides them with much more information at their disposal than their disadvantaged counterparts.

These dramatic divergences clearly reflect disparities in the relative levels of material, social, and temporal resources at the disposal of the two groups of students. As we have seen, despite similar levels of academic achievement, advantaged students enjoy much more favorable access conditions to informational resources and information technologies than their disadvantaged counterparts. Differences between the two groups are vivid illustrations of Bourdieu's habitus, the internalized sense of how to relate to the social and institutional environment (Bourdieu, 1990). The term habitus denotes a set of dispositions and predispositions that tells the individual what it means to act appropriately or inappropriately in any given situation, what to expect from one's social and institutional milieu, and how to pursue one's goals within this milieu. This internalized "cognitive-motivational system" (Lizardo, 2004) incorporates the past experiences of the individual (Bourdieu, 1990). At the same time, it points forward to probable and improbable futures. It tells the individual which goals can be attained and which objectives lie beyond the bounds of the possible.

In contemporary American society, the generalized habitus young adults and teenagers bring to their academic and college-related activities is conditioned by the individual's location within a stratified system of class relations where individuals are expected to pursue upward mobility, even if it means "swimming upstream" (Vaisey, 2010). This habitus differs by the individual's class in both subtle and consequential ways. It bears the imprint of past class-specific experiences. In this context, even as the working-class individual encounters a generalized ethic that holds individuals responsible for their own social and economic trajectories (Sharone, 2007), the individual is likely to envision oneself as someone who exerts relatively little control over one's institutional and social environment as well as one's socioeconomic trajectory. Yet, despite the cultural fiat to seek upward mobility in American society, working-class individuals are also more likely to shy away from asserting their own interests and goals in their dealings with institutional representatives, deferring to their authority in ways that middle-class Americans do not (Lareau, 2003). It should therefore be no surprise that these same youth internalize a strategy that defers to authority in their information-acquisition for academic work and ultimately the college search, thus impacting their futures.

Here we see that the ability to internalize a sense of control over one's offline environment translates into online endeavors and sense of agency. Unlike the workingclass American, middle-class Americans are more likely to bring agency to their dealings with their social and institutional milieus because they know how to deal effectively with these parts of their environment (Lareau, 2003). In short, middle-class American young adults navigate their social and institutional environments equipped with considerably more social and institutional self-efficacy (Bandura, 1997) than their working-class counterparts. This sense of self-efficacy not only enables them to act more assertively in their dealings with institutional and social environments but also to envision more ambitious educational and occupational aspirations for themselves (Vaisey, 2010). 
50 From the findings of the study, it is clear that the relative sophistication of advantaged students' informational practices depends on the relative ease with which they gain access to both offline and online sources of information. At the same time, these students, by contrast with their disadvantaged counterparts, approach the information-acquisition and assessment processes with a substantially greater sense of social and institutional agency, as well as a greater sense of self-efficacy. Their enhanced sense of self-efficacy derives from the more favorable social and economic conditions, which they enjoyed in the years leading up to their high school careers. Experiencing a relative abundance of time and material resources on a daily basis, they did not acquire the "taste for the necessary" (Bourdieu, 1990) that undercuts the self-efficacy of their counterparts burdened with much more pressing temporal and material scarcities.

51 This article shows that information-acquisition and assessment practices must be understood in light of individuals' informational environments as well as their material and temporal circumstances. The rich empirical findings demonstrate how normative informational environments are both the result of economic class and a contributor to class reproduction. At the same time, it demonstrates how offline and online informationacquisition practices impact each other, as well as being impacted by scarcities experienced by individuals over time. Significantly, this process potentially has profound consequences for individuals' life chances, especially college applications. At least during their high school careers, unless there is an intervention, many of the students remain at a disadvantage in their encounters with new media. Notwithstanding their often extraordinary efforts to overcome the disadvantages of limited access to informational resources, many cannot keep pace with their better endowed counterparts. This being said, future research is needed to see how disadvantaged students may succeed in beating the odds and make the transition to autonomous information-assessment. Unearthing the crucial factors that catalyze this evolution is the task of future research on the contours of informational advantage.

\section{BIBLIOGRAPHY}

ALFORD Robert R. (1998). The Craft of Inquiry. New York, Oxford University Press.

BANDURA Albert (1997). Self-efficacy: The Exercise of Control. New York, Freeman.

BOURDIEU Pierre (1985). “The Social Space and the Genesis of Groups", Theory and Society, 14(6), pp. 723-744.

BOURDIEU Pierre (1990). The Logic of Practice, Stanford, Stanford University Press.

COTTEN Shelia R. \& JELENEwicz Shameeka M. (2006). “A disappearing digital divide among college students? Peeling away the layers of the digital divide", Social Science Computer Review, 24(4), pp. 497-506. 
DiMAGgio Paul, HARGitTAi Eszter, CELESTE Coral \& SHAFER Steven (2004). "Digital inequality: from unequal access to differentiated use", in Neckerman Kathryn (ed.), Social Inequality, New York, Russell Sage Foundation, pp. 355-400.

DIMAGGIO Paul \& BONIKOWSKI Bart (2008). "Make Money Surfing the Web? The Impact of Internet Use on the Earnings of U.S. Workers”, American Sociological Review, 73(2), pp. 227-250.

EMERSON Robert M. (1983). Contemporary Field Research a Collection of Readings, Prospect Heights, Waveland Press.

HAMELINK Cees J. (2001). The Ethics of Cyberspace, London, Sage.

HASSANI Sara Nephew (2006). "Locating digital divides at home, work, and everywhere else", Poetics, 34(4-5), pp. 250-272.

KUHLTHAU Carol C. (2004 [1993]). Seeking Meaning. A Process Approach to Library and Information Services, Norwood, Ablex Publication Company.

KotAmraju Nalini P. (2003). “Art versus Code: The Gendered Evolution of Web Design Skills”, in Howard Philip N. \& Jones Steve (dir.), Society Online: The Internet in Context, Sage, Thousand Oaks. LAREAU Annette (2003). Unequal Childhoods: Class, Race, and Family Life, Berkeley, University of California Press.

LIZARDO Omar (2004). The cognitive origins of Bourdieu's habitus, Journal for the Theory of Social Behaviour, 34(4), pp. 375-401.

LUKER Kristin (2009). Salsa dancing into the social sciences: research in an age of info-glut, Cambridge, MA, Harvard University Press.

MCMILLAN Sally J. \& MORRISON Margaret (2006). "Coming of age with the internet: A qualitative exploration of how the internet has become an integral part of young people's lives", New Media \& Society, 8(1), pp. 73-95.

MESCH Gustavo \& TALMUD Ilan (2010). The Social World of Adolescence in the Information Age, New York, Routledge.

PEW (2008). "Pew Internet and American Life Project", April 8 - May 11, 2008 Tracking Survey, Washington, D.C., Pew Internet and American Life Project.

PEW (2010). “Who's Online Trend Data”, Washington, D.C., Pew Internet and American Life Project.

PETER Jochen \& VALKENBURG Patti M. (2006). “Adolescents' internet use: Testing the 'disappearing digital divide' versus the 'emerging digital differentiation' approach”, Poetics, 34(4-5), pp. 293-305.

ROBINSON Laura (2009). “A Taste for the Necessary: A Bourdieuian approach to digital inequality", Information, Communication, \& Society 12(4), pp. 488-507.

SHARONE Ofer (2007). “Constructing Unemployed Job Seekers as Professional Workers: The Depoliticizing Work-Game of Job Searching”, Qualitative Sociology, 30(4), pp. 403-416.

schradiE Jen (2011). "The Digital Production Gap: The Digital Divide and Web 2.0 Collide", Poetics, 39(2), pp. 145-168.

scHULZ Jeremy (2012). “Talk of Work: Transatlantic Divergences in Justifications for Hard Work Among French, Norwegian, and American Professionals", Theory and Society, 41(6), pp. 603-634. 
VAISEY Stephen (2010). "What People Want: Rethinking Poverty, Culture, and Educational Attainment", Annals of the American Academy of Political and Social Science, 629(1), pp. 75-101.

VAN DIJK, Jan A. G. M. (2005). The Deepening Divide: Inequality in the Information Society, Thousand Oaks, Sage.

WITTE James C. \& MANNON Susan E. (2010). The Internet and Social Inequalities, New York, Routledge.

\section{NOTES}

1. I would like to express my appreciation to both the RESET reviewers and the editors, Sébastien François and Samuel Coavoux, for their insightful recommendations. I would also like to thank Sheila Cotten for her valuable commentary on the project. Deep appreciation is due to the dedicated educators and students in my fieldsites, as well as SCU student-researchers. In addition, I would like to acknowledge generous funding from the Santa Clara University Center for Science, Technology, and Society; Bannan Institute, Ignatian Center for Jesuit Education; SCU Internal Research Grants Program; and the SCU Faculty-Student Research Assistant Award Program

2. Readers already familiar with the American university system will wish to skip this footnote. In American English, the words college and university are often used interchangeably, although technically a college is an institution that grants the Bachelor of Arts (B.A.) or Bachelor of Science (B.S.). By contrast, universities also grant postgraduate degrees such as a Master of Arts (M.A.), Master of Business Administration (M.B.A.), and doctorate (Ph.D.). Whether a public or private institution, the descriptors "four year" or "four-year school" refer to both colleges and universities granting the B.A./B.S. degree because these degrees usually require four years of study. It may also be noted that these acronyms may also follow the tradition of Latin degree names, which appears to "invert" the acronyms: A.B., S.B., A.M., etc.

3. See: http://www.cde.ca.gov/sp/sw/t1/titleparta.asp (referenced April 18, 2011).

4. All names of individuals and institutions have been replaced by pseudonyms to protect anonymity. Grammar has been corrected when necessary for clarity.

5. See Robinson (2009) for various strategies used to obtain internet access outside of the home.

6. Readers already familiar with the California public university system will wish to skip this footnote. The state of California funds three main kinds of public educational institutions at the college-level: UCs, CSUs, and community colleges (CSU stands for California State University as in CSU Long Beach. UC stands for University of California as in UCLA or UC Berkeley). UCs and CSUs grant four-year degrees, but are generally less expensive than private universities. Although there is a hierarchy of universities within each system, in general the University of California system is both more expensive and has greater prestige than the California State University system. By contrast, community colleges have the lowest relative prestige and the lowest price tag. A community college is most often a local, public institution with few admission requirements that is open to the general public. Community colleges provide 1) general education requirements for the first two years of a four-year degree preparing students to transfer, 2) a terminal two-year degree, an Associate of Arts (A.A.), and 3) skilled occupational training and certification of varying duration. 


\section{ABSTRACTS}

This article begins to shed light on how informational advantage affects the use of new media for information-acquisition and assessment. Drawing on material culled from one-on-one and smallgroup interviews with high school students in an agricultural region of California, the article examines high achievers committed to academic excellence in preparation for college. However, while they share the same educational goals, not all of these students have access to the same informational resources. Informationally advantaged students' access to new media, traditional media, and social networks distinguishes them from their informationally disadvantaged counterparts who lack access to both online and offline resources. Examination reveals how these disparities in access to informational resources have consequences for the students' capacity to assess information relevant to schoolwork as well as college planning. Students with plentiful media resources adopt autonomous strategies vis-à-vis the assessment of information for both schoolwork and college searches. By contrast, students without informational resources are forced by necessity to rely on others, ultimately leading them to develop a dependence on trusted opinions in order to assess information. In relating informational environments to these assessment strategies, the article reveals the repercussions of informational advantage for schoolwork and college planning activities increasingly dominated by online resources.

Cet article vise à montrer les effets d'un avantage informationnel sur les usages des nouveaux médias liés à l'acquisition et à la vérification d'informations. Il se concentre sur les meilleurs élèves, ceux qui s'orientent vers un parcours universitaire long et qui entendent y exceller, à partir d'une enquête par entretiens en face-à-face et par petits groupes, avec des lycéens d'une région rurale de Californie. Quoi qu'ils partagent le même objectif, tous ces lycéens ne bénéficient pas des mêmes ressources informationnelles. Les plus dotés disposent d'accès aux médias, nouveaux comme traditionnels, et à des réseaux sociaux qui les distinguent des plus défavorisés, qui manquent, eux, de ressources en ligne comme hors ligne. L'analyse révèle que ces inégalités d'accès aux ressources ont des conséquences sur la capacité des étudiants à juger de la pertinence des informations auxquelles ils ont accès, pour le travail scolaire comme pour la préparation du travail universitaire. Les élèves les mieux dotés peuvent adopter des stratégies de vérification autonome de l'information. A l'inverse, les moins dotés se voient forcés de s'appuyer sur des opinions tierces, et deviennent dès lors dépendantes de ces dernières pour vérifier l'information. La description de ces environnements informationnels montre les répercussions de cet avantage informationnel pour les activités scolaires, et de préparation du travail universitaire, qui s'appuient toutes deux largement sur les ressources disponibles en ligne.

\section{INDEX}

Mots-clés: recherche d'information, inégalités numériques, habitus, handicap, éducation Keywords: information seeking, digital inequality, habitus, disadvantage, education 
AUTHOR

LAURA ROBINSON

Santa Clara University, Department of Sociology 